\title{
Day-to-day variation in sea-surface temperature reduces sooty tern Sterna fuscata foraging success on the Great Barrier Reef, Australia
}

\author{
Carol A. Erwin*, Bradley C. Congdon \\ School of Tropical Biology, James Cook University, PO Box 6811, Cairns, Queensland 4870, Australia
}

\begin{abstract}
Many seabird species threatened by global climate change are found mainly or exclusively in tropical regions. A shortage of long-term data linking climatic variation, oceanography and tropical seabird reproductive biology at both within- and between-season temporal scales means that the potential impact of climate change on these species is largely unknown. The sooty tern Sterna fuscata, an almost ubiquitous tropical seabird, has been declining on the Great Barrier Reef (GBR), Australia, over the last 3 decades. We examined the relationship between sooty tern foraging success and sea-surface temperature (SST) at Michaelmas Cay over 2 consecutive breeding seasons. Consistent patterns were observed with significant negative relationships between day-to-day variation in SST and both the amount of food fed to chicks and the feeding frequency during the latter two-thirds of each breeding season. At the beginning of each breeding cycle, rapid changes in foraging success highlighted that other within-season mechanisms also influence sooty tern reproductive potential. Our results suggest a previously undescribed spatial and temporal link between SST and sooty tern reproduction. Combined with previous findings for the southern GBR, this suggests that SST variation can influence the foraging success of multiple tropical seabird species at a reef-wide scale and implies a significant negative effect of forecasted climatic changes on seabirds breeding on the GBR.
\end{abstract}

KEY WORDS: Foraging success · Sea-surface temperature $\cdot$ Global warming $\cdot$ Within-season effects Sterna fuscata $\cdot$ Great Barrier Reef

\section{INTRODUCTION}

Increasingly, human-induced climate change is being identified as a major threat to seabird conservation on a global scale. Historically, and primarily in temperate regions, seabird population fluctuations and declines have been frequently associated with longterm and seasonal-scale effects of climate variation (Veit et al. 1997, Lyver et al. 1999, Dunlop et al. 2002), with individual species responding differently to temperature anomalies depending upon their diet (Kitaysky \& Goluvova 2000, Inchausti et al. 2003) and dispersal characteristics (Frederiksen et al. 2004).

Many species threatened by climate change are found mainly or exclusively in tropical oceans (Gaston 2001). Despite this, a scarcity of long-term datasets linking climatic variation, foraging ecology and reproductive success in these regions means that predicting the potential impact of climate change on tropical seabirds remains difficult. From data that are available for tropical systems, extreme variations in reproductive performance have been related to both seasonal-scale (Ramos et al. 2002, Smithers et al. 2003) and longerterm (Schreiber \& Schreiber 1984, Ainley et al. 1988) processes associated with the El Niño Southern Oscillation (ENSO). Recently, in addition to these interannual effects, intra-annual effects have been documented in a tropical seabird by directly correlating daily changes in provisioning rates, meal sizes and chick growth with day-to-day fluctuations in seasurface temperature (SST) (Peck et al. 2004). While it is clear from these data that SST impacts tropical Pro- 
cellariiform (tube-nosed) seabirds, there is currently a critical lack of information on the trophic mechanisms responsible for these impacts and on whether this is a general phenomenon affecting a range of tropical seabird taxa.

Prey abundance and seabird reproductive biology have been significantly correlated many times (Anderson et al. 1982, Burger \& Piatt 1990). In particular, growth patterns in pelagic seabirds are frequently presumed to reflect characteristics of food supply (Ashmole \& Ashmole 1967), with short-term fluctuations in resource availability being directly linked to altered growth rates (Feare 1976, Suryan et al. 2002). Foraging seabirds have also been shown to respond rapidly to SST changes in foraging areas (Hunt et al. 1992). Similarly, prey abundance and availability have also been linked to climate-associated variation in SST, at both inter- and intra-annual temporal scales (Spear et al. 2001, Stenseth et al. 2002, McIlwain 2003). Combined, these findings suggest that short-term reproductive success in seabirds (i.e. as measured by day-to-day variations in foraging success and/or chick growth) directly reflect prey abundance and availability at similar temporal scales and, thus can be used as an immediate indicator of food availability.

The sooty tern Sterna fuscata is the most abundant seabird species in tropical regions (Schreiber et al. 2002). As measured by food consumed, it is also the principal tropical species and fourth most important species world-wide (Brooke 2004). Sooty terns are found breeding on many of Australia's tropical vegetated coral cays, offshore islands and stacks (Higgins \& Davies 1996). Michaelmas Cay is a highly important tropical seabird nesting site in the Great Barrier Reef (GBR) World Heritage Marine Park, Australia (GBRMPA 2002), and constitutes a major nesting site for sooty terns (King 1985). Significant declines in sooty tern populations have been recorded throughout the GBR over a 15 to 24 yr period, with marked declines occurring between about 11 and $12^{\circ} \mathrm{S}$ (Blaber et al. 1998). From 1984 to 1994 sooty tern numbers declined by $26 \%$ at Michaelmas Cay (GBRMPA 1998), and, over a $24 \mathrm{yr}$ period, by $84.4 \%$ at Raine Island, another important breeding site in the far northern sector of the GBR (Batianoff \& Cornelius 2005).

Elsewhere in Australia, the sooty tern is listed as vulnerable on the schedules of the New South Wales Threatened Species Conservation Act based on its breeding ecology, distribution and poor recovery potential (Lunney et al. 2000). In the Seychelles this species has been declining since the beginning of the century (Ridley \& Percy 1958). Although long-term declines have been attributed primarily to human consumption of eggs (Feare 1976), more recent declines have not, to our knowledge, been investigated in the context of changing climatic regimes. Similarly, at Christmas Island in the Central Pacific, the breeding colony for this species has been reduced to approximately $1.5 \%$ of its known original size (Schreiber et al. 2002), with declines being attributed to a combination of ENSO influences and human predation.

Sooty terns have been shown to fare poorly throughout most of their range during periods of El Niño conditions (Ashmole 1963, Schreiber \& Schreiber 1984, Duffy 1990). In temperate Australia, almost complete reproductive failure was documented for this species at Lord Howe Island during the 2002 ENSO event (L. O'Neill pers. comm.). The response of this species to ENSO events is generally unknown in the GBR region. However, ENSO events have caused reduced provisioning and reproductive failure in other breeding seabirds on the GBR (Hoegh-Guldberg 1999, Smithers et al. 2003). As a result of the enhanced greenhouse effect, recent SSTs on the GBR are the warmest in a century of instrumental record (Lough 2000), with further increases predicted (IPCC 2001). Similarly, since the 1970s, El Niño events on the GBR have apparently increased in both frequency and intensity (Hughes 2003).

These correlated long-term trends suggest that climatic factors, including increasing SSTs, may be, in part, responsible for the previously observed population decline of sooty terns on the GBR. If so, negative impacts may be manifested at either the long-term seasonal, or within-season temporal scale. Consistent evidence that small-scale variation in SST affects food availability, provisioning and growth on a daily basis in the southern GBR (Peck et al. 2004) suggests that there may be an important and as yet undocumented link between sooty tern population declines at Michaelmas Cay and short-term fluctuations in SST. More importantly, findings that populations of the most abundant seabird species in the tropics are declining could indicate major changes in the structure and functioning of tropical marine ecosystems that could be affecting other species. Therefore, the primary aim of this study was to investigate the relationship between sooty tern foraging success and intra-seasonal SST variation within near-colony foraging areas of the GBR. Specifically, we tested whether day-to-day fluctuations in SST impacted chick provisioning, resulting in changes in meal size, feeding rate and/or meal composition.

\section{MATERIALS AND METHODS}

Michaelmas Cay is a small vegetated sand cay located on Michaelmas Reef $\left(16^{\circ} 36^{\prime} \mathrm{S}, 145^{\circ} 59^{\prime} \mathrm{E}\right.$, Fig. 1) in the Cairns section of the GBR. The cay is $\sim 1.8$ ha in size, with a vegetated area of available nest- 


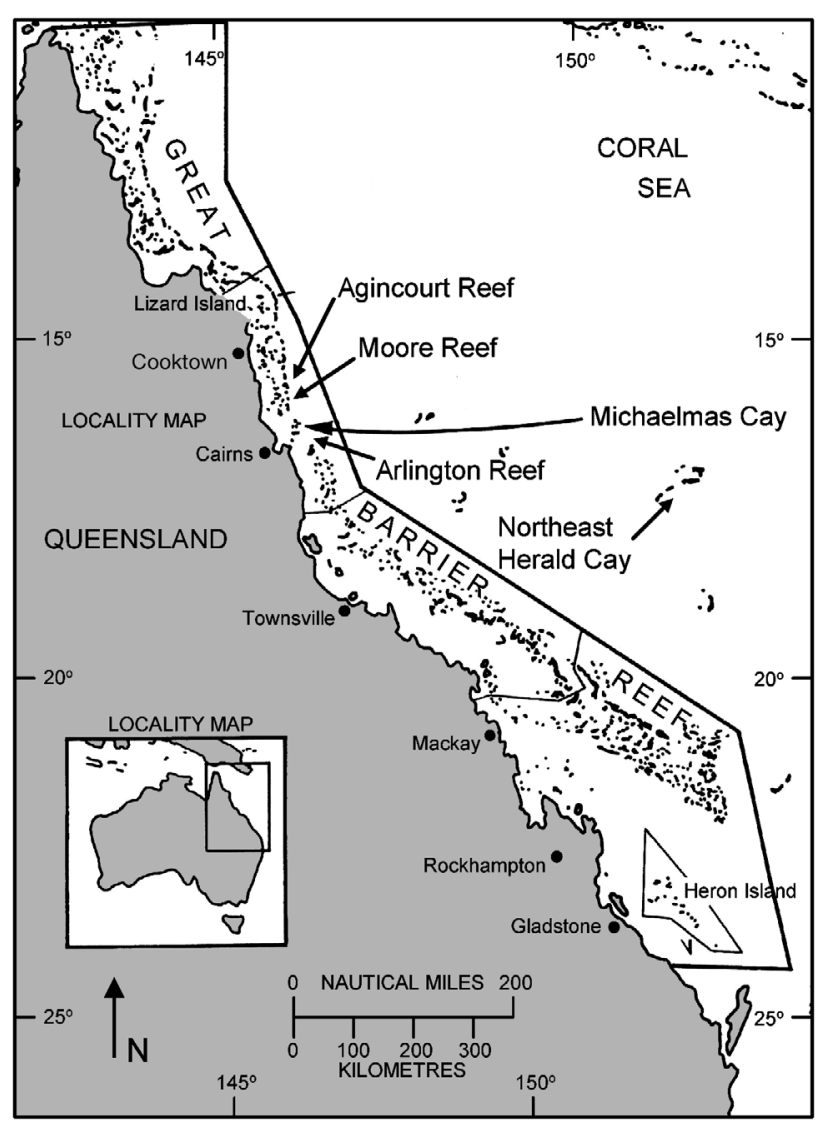

Fig. 1. Map of Queensland, Australia, and the Cairns section of the Great Barrier Reef (GBR) showing locations of Michaelmas and Northeast Herald Cays and Agincourt, Arlington and Moore Reefs (adapted from GBRMPA 1986)

ing habitat of approximately $180 \mathrm{~m}^{2}$. Data on foraging success and SST were collected at Michaelmas Cay over the same stage of 2 independent breeding cycles: $16 \mathrm{~d}$ from 1 September to 3 October 2004 and $19 \mathrm{~d}$ from 6 May to 22 June 2005 (data were not collected every day during these 2 periods). At Michaelmas Cay, sooty terns Sterna fuscata breed at irregular intervals (King et al. 1992) and exhibit a mean breeding periodicity of $\sim 10.35 \pm 0.91$ mo (QPWS unpubl. data). Data collection periods in this study represent approximately the first 36 and $52 \%$ of each breeding cycle, respectively (Le Corre 2001, QPWS unpubl. data). During 2004, all data were collected remotely, i.e. no handling or banding of the chicks or adults was undertaken. During the 2005 breeding season a subset of 42 same-aged chicks were banded for individual recognition at $3 \mathrm{~d}$ of age.

Sooty tern chicks become mobile at an early age $(<10 \mathrm{~d})$, and crèche under dense shrubs where available. During each observation period, adult feeding rates in a spatially defined area of the colony containing a different but known number of either all unbanded (2004) ( $\mathrm{n}=73$ to 157 ) or groups of both banded and unbanded (2005) ( $\mathrm{n}=20$ to 65 ) chicks at nests ( $<10 \mathrm{~d}$ of age) and in crèches ( $>10 \mathrm{~d}$ of age) were monitored continuously using binoculars. Areas of the colony and the numbers of chicks to be monitored were redefined at the beginning of each observation period. Observations occurred for at least $1.4 \mathrm{~h}$ and up to $3.8 \mathrm{~h}$ associated with the same period each day (10:45 to $14: 15$ h). Multiple logistical constraints precluded data collection outside these hours; however, standardising observations over the same period each day serves as a relative measure of day-to-day foraging success.

Meal index ( $\left.M_{\text {INDEX }}\right)$ and feeding frequency $\left(F_{\text {FREQ }}\right)$. During 2004, when no chicks were banded or handled, provisioning was monitored using binoculars only. Food items delivered to chicks were quantified into a 'meal index' ( $\left.M_{\text {INDEX }}\right)$ based on prey linear dimensions, using the size of the adult's bill as a reference, a technique which has been used previously (Forbes \& Sealy 1990, Shealer 1998). Food items that were approximately the same length as the adult's bill were given a value of 1 . Items that were approximately 1.5 times the length of the bill were assigned a value of 1.5 , and so on. Items that were wider or taller than the bill were treated in the same manner. This technique assumes a linear relationship between prey size and volume (i.e. that prey have zero depth) and so may underestimate slightly the caloric value of larger prey items. Thus, $M_{\text {INDEX }}$ provides an index of relative change in meal size among days, rather than absolute measure of meal size (Suryan et al. 2002). Using the bill as a ruler also assumes little variation in bill size between individual adult sooty terns at a single breeding colony; a realistic assumption based on available data (Higgins \& Davies 1996).

For each chick that was fed in the observation group over the observation interval, a $M_{\text {INDEx }}$ value was calculated based on the relative length $\times$ width of each prey item multiplied by the number of prey items of that size + the length $\times$ width $\times$ number of prey items for each differently sized prey item. To standardise $M_{\text {INDEX }}$ between observation periods, a mean $M_{\text {INDEX }}$ was computed for each observation period by dividing total food by both the number of chicks and the number of minutes per observation period.

In 2005, provisioning was monitored as in 2004. In addition, in 2005, a 'food curve' was generated, so that $M_{\text {INDEX }}$ values could be converted into an index of meal mass in grams. On $3 \mathrm{~d}$ of data collection $(12,14$ and 17 May) colour-banded chicks ( $\mathrm{n}=23$ ) were weighed both in the morning, prior to their first meal (08:00 h), and in the afternoon, directly subsequent to $8 \mathrm{~h}$ of visual observations (16:00 h). A meal mass equivalent of $M_{\text {INDEX }}$ was estimated by regressing the mass increment for each chick, based on the differences 
between the morning and afternoon weighings, against $M_{\text {INDEX }}$ for the same chicks over the same period. Derivation of meal sizes from chick mass changes is a standard method of obtaining relative measures of adult foraging success for comparative purposes (Phillips \& Hamer 2000, Peck et al. 2004). As chicks lose mass during the day, due to digestion, respiration, defecation and evaporative cooling, the difference in mass between the morning and afternoon weights does not represent the total mass of food received (Ricklefs et al. 1985). Thus, mass meal values serve as a relative measure of mass gain per chick from the visually observed $M_{\text {INDEX }}$. Mass values were standardised for stage of chick growth by dividing each chick's daily mass change by their age in days.

The average size of all prey items of known size for each day of observation was used to assign an $M_{\text {INDEX }}$ value to prey items of unknown size (i.e. when a food item was exchanged, but the observer could not determine the size). The proportion $( \pm \mathrm{SE})$ of prey items that had to be assigned a mean value was $0.063 \pm 0.010$ in 2004 and $0.052 \pm 0.014$ in 2005 . The adult feeding frequency $\left(F_{\text {FREQ }}\right)$ was also recorded. This variable comprised the total number of deliveries per observation period divided by the number of chicks in the observation area and the number of minutes of observation.

Squids make up the primary prey items in the diet of sooty terns (53 to $70 \%$ ), while fishes make up 33.2 to $46 \%$ (Harrison et al. 1983, Higgins \& Davies 1996, Surman et al. 2002). In this study, food items were categorised as fish, squid, or unknown. Immature fish are of only slightly higher energy density than squid (Davis et al. 1998), and $M_{\text {INDEX values obtained in our }}$ study were consistent with previous observations that terns feed primarily on immature fishes (Shealer 1998). Thus, each prey type was assumed to be of approximately equal calorific value per gram provided. Meal composition as a percentage of each prey type was determined for each day of the study.

Adjustments for chick age and changing energy demands. Analyses of $M_{\text {INDEX }}$ or $F_{\text {FREQ }}$ examined changes in the amount of food reaching each chick per unit time. Since adults may adjust food loads or feeding frequencies relative to the energetic demands of chicks (Feare 1976), $M_{\text {INDEX }}$ and $F_{\text {FREQ }}$ were also adjusted for potential changes in energy requirements with chick age. This procedure required estimates of both chick age and of the relationship between chick energy demands and chick age.

Sooty terns breeding in different subsections of a colony nest relatively synchronously (Feare 1976, authors' pers. obs.). This means that at any single point in time, the majority of chicks in a definable area of colony are of equivalent ages. In 2004, the chick age estimates used to adjust $M_{\text {INDEX }}$ and $F_{\text {FREQ }}$ data were the median values estimated for each similarly aged group of chicks observed during an observation interval. These age estimates were derived from comparison with time-series photographs taken of multiple known-age chicks.

For sooty tern young, the growth rate and shape of the growth curve are such that chick energy demands increase more rapidly during the first week of growth, but then increase relatively uniformly throughout the developmental period (Ricklefs \& White 1981). For example, during the first $20 \mathrm{~d}$, the energy requirement increases from 55 to $80 \%$ of the maximum. This suggests an approximately linear relationship between the energy requirements of sooty tern neonates and age. If so, dividing $M_{\text {INDEX }}$ by chick age is an appropriate adjustment for increasing energy demands.

SST data. Sooty terns are rarely found feeding within sight of land (Ashmole 1963). However, the distance travelled from nesting to foraging grounds is variable among years and colonies (Ashmole \& Ashmole 1967) as well as according to reproductive status (Flint 1991). Outside the Australian region, sooty terns have been observed foraging 80 to $200 \mathrm{~km}$ from their breeding colonies (Dinsmore 1972, Feare 2002). In Australia, this species has been observed foraging 480 to $600 \mathrm{~km}$ from their colonies, on the edge of the continental shelf (Surman \& Wooller 2003).

To account for the fact that foraging adults may experience conditions different to those at the breeding colony, SST data were collected at different spatial scales from 4 independent sources. From 15 September to 3 October (the second half of the 2004 study period) and from 6 May to 22 June (the entire study period in 2005) dual IBUTTON (Maxim/Dallas Semiconductor) data loggers were fastened to a permanent mooring in Michaelmas Cay harbour at $1 \mathrm{~m}$ depth below the sea surface. These data loggers recorded hourly SST measurements in the waters directly adjacent to Michaelmas Cay ( $\mathrm{SST}_{\mathrm{MC}}$ ) that were later converted to daily averages. IBUTTON data at Michaelmas Cay for 1 through 14 September 2004 were not obtained due to equipment failure.

In order to generate SST values for the first portion of the 2004 study period, as well as to determine the comparability between daily SST collected locally and more broadly, SST $_{\text {MC }} 2004$ data were compared with daily average SST data from Great Barrier Reef Marine Park Authority (GBRMPA) and Australian Institute of Marine Science (AIMS) monitoring stations on multiple outer reefs in the Cairns section of the GBR, as well as at a location in the Coral Sea, which is within the sooty tern foraging range (at least $500 \mathrm{~km}$ in the Australian region [Higgins \& Davies 1996, Surman \& Wooller 2003]). At each monitoring station, average daily SSTs were computed from the average of SST 
measurements recorded every 30 min at 1 to 2 depths per station (4 to $7 \mathrm{~m}$ ).

Fisheries. Daily catch and effort records from the Eastern Tuna and Billfish Fishery (ETBF) were obtained from Australian longline daily fishing logbooks (ALO5 logtypes) housed at the Australian Fisheries Management Authority (AFMA). Daily catch (kg) data were analysed for all days during each study interval. Latitudes were limited to between 13.0 and $19.99^{\circ} \mathrm{S}$ and longitudes to between 142.5 and $150.99^{\circ} \mathrm{E}$. Data from this area were used to estimate the relationship between sooty tern foraging success and the relative abundance of some of the most important obligate commensal sub-surface marine predators that forage in association with sooty terns. Almost all tropical feeding terns, noddies and shearwaters occur where surface-feeding tunas or mammals are present ( $\mathrm{Au} \&$ Pitman 1986, Jaquemet et al. 2004), and tonnage capture data indicate the presence and spatial abundance of these taxa.

Statistical analyses. All data were tested for normality and homogeneity of variance. Linear regressions were then calculated where those assumptions were met. To account for the very small values associated with $M_{\text {INDEX }}$ and $F_{\text {FREQ }}$ data, these variables were linearly transformed by multiplication by 1000 . The standardised foraging variables $\left(M_{\text {INDEX }}, F_{\text {FREQ }}\right.$ and meal composition) were then tested against SST measurements that were recorded primarily at Michaelmas Cay in both seasons (see 'Results' for justification). To determine the influence of daily fluctuations in SST on the observed pattern of inter-annual foraging success, ANCOVA analyses were conducted with $M_{\text {INDEX }}$ and $F_{\text {FREQ }}$ as dependent variables, year as the fixed factor and SST as the covariate. The relationship between $M_{\text {INDEX }}$ and chick mass change was established by regressing $\log _{10}$ chick mass change and $\log _{10}$ chick mass change per day of age against the $M_{\text {INDEX }}$ values. $\log _{10}$ transformations were required to meet the assumption of normality. Different levels of variance were observed between years for fisheries data (Levene's F-test; see 'Results'). As a consequence, the between-year comparisons were undertaken using a non-parametric test that adjusted for unequal variance among samples (Mann-Whitney $U$-test). All statistical analyses were performed using SPSS for Windows Version 11.0.1 (SPSS 2001).

\section{RESULTS}

\section{SST data}

$\mathrm{SST}_{\mathrm{MC}} 2004$ data were compared with daily SST data from the GBRMPA temperature monitoring stations at
Arlington $\left(16^{\circ} 43^{\prime} \mathrm{S}, 146^{\circ} 03^{\prime} \mathrm{E}\right)$ and Moore Reefs $\left(16^{\circ} 52^{\prime} \mathrm{S}, 146^{\circ} 12^{\prime} \mathrm{E}\right)\left(\mathrm{SST}_{\text {Broad }}\right)$ (Fig. 1). These monitoring stations are on outer reefs in the Cairns section of the GBR Marine Park, approximately 15 and $40 \mathrm{~km}$ from Michaelmas Cay, respectively. $\mathrm{SST}_{\text {Broad }}$ values from 15 September to 3 October were compared with $\mathrm{SST}_{\mathrm{MC}}$ values collected during the same period. The 2 temperatures were highly correlated $\left(F_{1,7}=30.364\right.$, adjusted $\mathrm{r}^{2}=0.786, \mathrm{p}=0.001 ; \mathrm{SST}_{\mathrm{MC}}=1.236 \mathrm{SST}_{\text {Broad }}-$ 6.022).

At the time of publication, SST data were not available from Arlington and Moore Reefs for the 2005 study periodi instead $\mathrm{SST}_{\mathrm{MC}}$ values were compared with SST data generated from the AIMS temperature monitoring station at Agincourt Reef $\left(16^{\circ} 02^{\prime} \mathrm{S}\right.$,

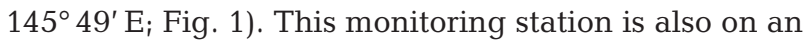
outer reef in the Cairns section of the GBR Marine Park, approximately $80 \mathrm{~km}$ from Michaelmas Cay. Daily values from Agincourt Reef were then used as a broad-scale measure of SST $\left(\mathrm{SST}_{\text {Agin }}\right)$ in 2005. $\mathrm{SST}_{\mathrm{MC}}$ values in 2005 were compared with $\mathrm{SST}_{\text {Agin }}$ values collected during the same period. The 2 temperatures were highly correlated $\left(F_{1,19}=116.153\right.$, adjusted $\mathrm{r}^{2}=$ $\left.0.852, \mathrm{p}<0.001 ; \mathrm{SST}_{\mathrm{MC}}=1.3 \mathrm{SST}_{\text {Agin }}-8.774\right)$.

$\mathrm{SST}_{\mathrm{MC}}$ data for both 2004 and 2005 were also compared with SSTs that were generated from a GBRMPA temperature monitoring station at Northeast Herald Reef $\left(16^{\circ} 56^{\prime} \mathrm{S}, 149^{\circ} 11^{\prime} \mathrm{E}\right)$, an isolated seamount in the Coral Sea, approximately $400 \mathrm{~km}$ from Michaelmas Cay (Fig. 1). Daily SSTs from Northeast Herald Reef ( $\left.\mathrm{SST}_{\mathrm{NEHerald}}\right)$ provided a very broad-scale measure of SST during both seasons. $\mathrm{SST}_{\mathrm{NEHerald}}$ values from 15 September to 3 October 2004 and 6 May to 22 June 2005 were compared with $\mathrm{SST}_{\mathrm{MC}}$ values collected during the same period; again the temperatures were highly correlated $\left(F_{1,39}=202.455\right.$, adjusted $\mathrm{r}^{2}=0.834$, $\mathrm{p}<0.001 ; \mathrm{SST}_{\mathrm{MC}}=1.200 \mathrm{SST}_{\mathrm{NEHerald}}-5.670$ ).

Significant correlations were found between SST at Michaelmas Cay and SST data from all other locations, suggesting that $\mathrm{SST}_{\mathrm{MC}}$ accurately reflects the variation in SST that sooty tern adults breeding at Michaelmas Cay experience throughout their foraging range. Therefore, $\mathrm{SST}_{\mathrm{MC}}$ was used as the general measure of sea-surface temperature variation in all further analyses.

\section{Foraging success in relation to SST}

During both 2004 and 2005, 2 distinctly different and temporally discrete relationships were evident between SST variation and sooty tern foraging success. Potential SST impacts were consistently observed only during the second two-thirds of the study period in each year (Fig. 2). 

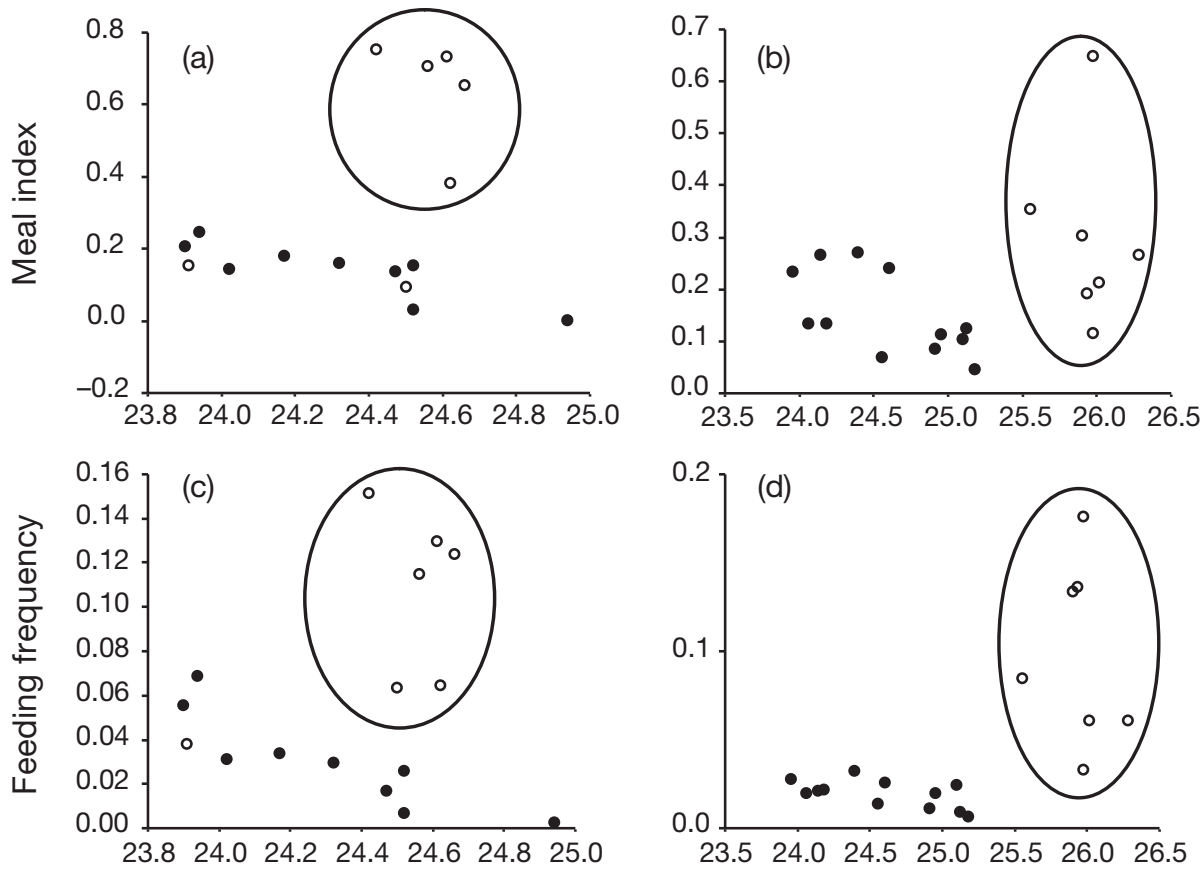

$\mathrm{SST}\left({ }^{\circ} \mathrm{C}\right)$

Fig. 2. Sterna fuscata. Effect of daily sea-surface temperature (SST) at Michaelmas Cay on day-to-day age-adjusted (a,b) meal in$\operatorname{dex}\left(M_{\text {INDEX }}\right)$ and $(c, d)$ feeding frequency $\left(F_{\text {FREQ }}\right)$ during $(\mathrm{a}, \mathrm{c})$ the first one-third $(0,1$ to 13 September $)$ and second two-thirds $(\bullet, 15$ September to 3 October) of 2004 and (b,d) the first one-third (o, 6 to 19 May) and second two-thirds (•, 23 May to 22 June) of 2005

Table 1. Sterna fuscata. Regression analysis results describing relationships between predictor variables (local- and broad-scale SSTs) and sooty tern foraging success in contrasting 'regimes' and both regimes combined (entire) during 2004 and 2005 , in terms of meal index $\left(M_{\text {INDEX }}\right)$ and feeding frequency $\left(F_{\mathrm{FREQ}}\right)$. Bold print denotes significant relationships

\begin{tabular}{|c|c|c|c|c|c|c|}
\hline Dependent variable & Year & Regime & Predictor & $F$ & Adjusted $\mathrm{r}^{2}$ & $\mathrm{p}$ \\
\hline \multirow[t]{6}{*}{$M_{\text {INDEX }}\left(\operatorname{chick}^{-1} \min ^{-1}\right)$} & \multirow[t]{3}{*}{2004} & $1 \mathrm{st}$ & $\mathrm{SST}_{\text {Broad }}$ & $F_{1,3}=0.525$ & -0.135 & 0.521 \\
\hline & & 2nd & $\mathrm{SST}_{\mathrm{MC}}$ & $F_{1,7}=2.249$ & 0.135 & 0.177 \\
\hline & & Entire & $\mathrm{SST}_{\text {Broad }}$ & $F_{1,14}=0.172$ & -0.058 & 0.685 \\
\hline & \multirow[t]{3}{*}{2005} & $1 \mathrm{st}$ & $\mathrm{SST}_{\mathrm{MC}}$ & $F_{1,5}=0.045$ & -0.189 & 0.840 \\
\hline & & 2nd & $\mathrm{SST}_{M C}$ & $F_{1,10}=7.459$ & 0.370 & 0.021 \\
\hline & & Entire & $\mathbf{S S T}_{M C}$ & $F_{1,17}=6.078$ & 0.220 & 0.025 \\
\hline \multirow[t]{6}{*}{$M_{\text {INDEX }}\left(\operatorname{chick}^{-1} \min ^{-1} \mathrm{~d}^{-1}\right.$ of age $)$} & \multirow[t]{3}{*}{2004} & $1 \mathrm{st}$ & $\mathrm{SST}_{\text {Broad }}$ & $F_{1,3}=0.763$ & -0.062 & 0.445 \\
\hline & & 2nd & $\mathbf{S S T}_{\mathrm{MC}}$ & $F_{1,7}=6.973$ & 0.427 & 0.033 \\
\hline & & Entire & $\mathrm{SST}_{\text {Broad }}$ & $F_{1,14}=0.738$ & -0.018 & 0.405 \\
\hline & \multirow[t]{3}{*}{2005} & $1 \mathrm{st}$ & $\mathrm{SST}_{\mathrm{MC}}$ & $F_{1,5}=0.113$ & -0.173 & 0.750 \\
\hline & & 2nd & $\mathrm{SST}_{\mathrm{MC}}$ & $F_{1,10}=6.246$ & 0.323 & 0.031 \\
\hline & & Entire & $\mathrm{SST}_{\mathrm{MC}}$ & $F_{1,17}=1.875$ & 0.046 & 0.189 \\
\hline \multirow[t]{6}{*}{$F_{\text {FREQ }}\left(\operatorname{chick}^{-1} \min ^{-1}\right)$} & \multirow[t]{3}{*}{2004} & $1 \mathrm{st}$ & $\mathrm{SST}_{\text {Broad }}$ & $F_{1,3}=0.893$ & -0.028 & 0.414 \\
\hline & & 2nd & $\mathbf{S S T}_{\mathbf{M C}}$ & $F_{1,7}=6.525$ & 0.409 & 0.038 \\
\hline & & Entire & $\mathrm{SST}_{\text {Broad }}$ & $F_{1,14}=0.116$ & -0.063 & 0.739 \\
\hline & \multirow[t]{3}{*}{2005} & $1 \mathrm{st}$ & $\mathrm{SST}_{\mathrm{MC}}$ & $F_{1,5}=0.215$ & -0.151 & 0.662 \\
\hline & & 2nd & $\mathbf{S S T}_{\mathbf{M C}}$ & $F_{1,10}=21.575$ & 0.652 & 0.001 \\
\hline & & Entire & $\mathrm{SST}_{\mathrm{MC}}$ & $F_{1,17}=4.044$ & 0.145 & 0.060 \\
\hline \multirow{6}{*}{$F_{\text {FREQ }}\left(\operatorname{chick}^{-1} \min ^{-1} \mathrm{~d}^{-1}\right.$ of age $)$} & \multirow[t]{3}{*}{2004} & $1 \mathrm{st}$ & $\mathrm{SST}_{\text {Broad }}$ & $F_{1,3}=1.339$ & -0.078 & 0.331 \\
\hline & & 2nd & $\mathbf{S S T}_{\mathbf{M C}}$ & $F_{1,7}=8.388$ & 0.480 & 0.023 \\
\hline & & Entire & $\mathrm{SST}_{\text {Broad }}$ & $F_{1,14}=0.223$ & -0.055 & 0.644 \\
\hline & \multirow[t]{3}{*}{2005} & $1 \mathrm{st}$ & $\mathrm{SST}_{\mathrm{MC}}$ & $F_{1,5}=0.154$ & -0.164 & 0.711 \\
\hline & & 2nd & $\mathbf{S S T}_{\mathrm{MC}}$ & $F_{1,10}=5.176$ & 0.275 & 0.046 \\
\hline & & Entire & $\mathrm{SST}_{\mathbf{M C}}$ & $F_{1,17}=11.632$ & 0.371 & 0.003 \\
\hline
\end{tabular}


During the 15 September to 3 October 2004 and again during 23 May to 22 June 2005 ('Foraging Regime 2') $\mathrm{SST}_{\mathrm{MC}}$ was a significant negative predictor of age-adjusted $M_{\text {INDEX }}$ (ANCOVA: $F_{1,17}=12.868$, adjusted $r^{2}=0.335, p=0.002$; Table 1, Fig. 3a). There was also a significant difference in the intercept of each regression line $\left(F_{1,17}=14.458, \mathrm{p}=0.001\right)$, but not in the slopes of the lines between years $\left(F_{1,17}=0.150\right.$, $\mathrm{p}=0.704$ ). Thus, during both 2004 and 2005, ageadjusted $M_{\text {INDEX }}$ declined at the same rate with increasing SST, but, for any given temperature, the $M_{\text {INDEX }}$ was consistently lower during 2004. For each $1^{\circ} \mathrm{C}$ increase in SST, age-adjusted $M_{\text {INDEX }}$ declined by $7.96 \%\left(F_{1,19}=9.463\right.$, adjusted $\mathrm{r}^{2}=0.297, \mathrm{p}=0.006$; ageadjusted $\left.M_{\text {INDEX }}=2.09-0.0796 \mathrm{SST}_{\mathrm{MC}}\right)$.

During these same periods, age-adjusted $F_{\text {FREQ }}$ was also significantly negatively correlated with $\mathrm{SST}_{\mathrm{MC}}$ (ANCOVA: $F_{1,17}=13.142$, adjusted $\mathrm{r}^{2}=0.495, \mathrm{p}=$ 0.002; Table 1, Fig. 3b). Again there was a difference in the intercepts of the regression line between years $\left(F_{1,17}=14.549, \mathrm{p}=0.001\right)$, but not between the slopes $\left(F_{1,17}=2.355, \mathrm{p}=0.143\right)$. Thus, during both years, ageadjusted $F_{\text {FREQ }}$ again declined at a similar rate with increasing SST, but, for any given temperature, $F_{\mathrm{FREQ}}$ was lower during 2004. For each $1^{\circ} \mathrm{C}$ increase in SST, age-adjusted $F_{\text {FREQ }}$ declined by $2.00 \%\left(F_{1,19}=19.314\right.$, adjusted $\mathrm{r}^{2}=0.478, \mathrm{p}<0.001$; age-adjusted $F_{\mathrm{FREQ}}=$ $\left.0.512-0.0200 \mathrm{SST}_{\mathrm{MC}}\right)$.

Significant negative relationships were also present for the non-age-adjusted $M_{\text {INDEX }}$ and $F_{\text {FREQ }}$ in 2005 (Table 1) and for non-age-adjusted $F_{\text {FREQ }}$ in 2004. However, no significant relationship was observed for $M_{\text {INDEX }}$ in 2004 when chick age was not accounted for (Table 1).

During the later portions of both study periods in each year when SST was a significant negative predictor of foraging success, absolute meal sizes $( \pm \mathrm{SE})$ also differed significantly between the 2 seasons, meal sizes being larger in 2005 (2004: $3.74 \pm 0.62 M_{\text {INDEX }} \mathrm{d}^{-1}$, 2005: $6.32 \pm 0.89 M_{\text {INDEX }} d^{-1}$; independent samples $t$ test: $t=-2.220$, df $=19, \mathrm{p}=0.039$ ).

From 6 to 13 September 2004 and from 6 to 19 May 2005 ('Foraging Regime 1') no significant effects of $\mathrm{SST}_{\mathrm{MC} / \text { Broad }}$ on $M_{\text {INDEX }}$ or $F_{\text {FREQ }}$ were observed (Table 1). During this period in 2004 there was on average $\sim 5$ times the age-adjusted $M_{\text {INDEX }}$ (Regime 1: $0.646 \pm 0.068 \mathrm{SE}$, Regime 2: $0.141 \pm 0.024 \mathrm{SE}$ ) and $\sim 3$ times as many meals relative to chick requirements (Regime 1: $0.117 \pm 0.014 \mathrm{SE}$, Regime 2: $0.030 \pm 0.0065$ $\mathrm{SE})$ brought to the colony for equivalent SSTs. This equates to 15 times as much food with no apparent temperature effect. Similarly, during this period in 2005, there was on average $\sim 2$ times the amount of food (Regime 1: $0.299 \pm 0.065$ SE, Regime 2: $0.152 \pm$ $0.023 \mathrm{SE}$ ) and $\sim 5$ times as many meals (Regime 1:
$0.979 \pm 0.020 \mathrm{SE}$, Regime 2: $0.0196 \pm 0.0063 \mathrm{SE}$ ) brought to the colony for equivalent SSTs. This equates to $\sim 10$ times as much food with no apparent temperature effect. Therefore, over a relatively short 1 to $2 \mathrm{~d}$ period in both years, food availability to foraging adult sooty terns decreased by approximately 1 order of magnitude, after which it did not recover and SST effects became apparent.

\section{Converting meal index $\left(M_{\text {INDEX }}\right)$ values into meal mass}

Significant positive relationships were observed between $M_{\text {INDEX, }}$ chick mass change $\left(F_{1,21}=12.551\right.$, adjusted $\mathrm{r}^{2}=0.344, \mathrm{p}=0.002 ; \log _{10}$ chick mass change $=$ $0.0782 M_{\text {INDEX }}+0.743$ ) and age-adjusted chick mass change $\left(F_{1,21}=15.626\right.$, adjusted $\mathrm{r}^{2}=0.399, \mathrm{p}<0.001$; $\log _{10}$ chick mass change per day of age $=0.0591 M_{\text {INDEX }}$ - 0.330; Fig. 4). Thus, each change of 1 meal index was equal to $0.0782 \mathrm{~g}$ and $0.0591 \mathrm{~g} \mathrm{~d}^{-1}$ of age. Furthermore,
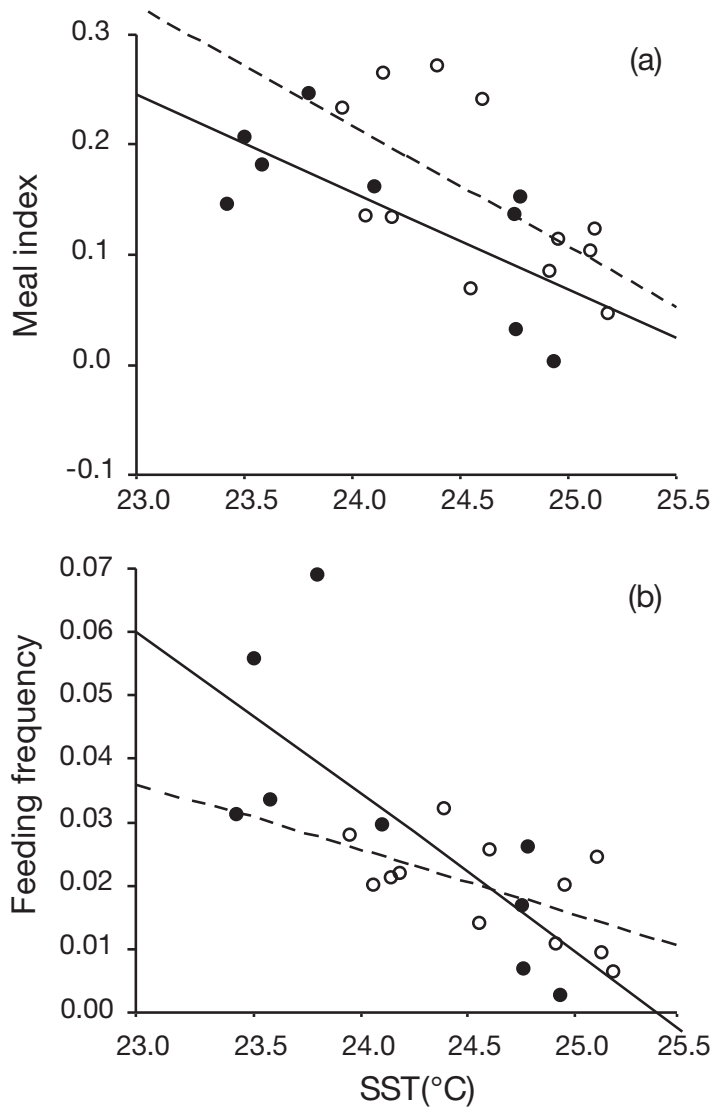

Fig. 3. Sterna fuscata. Effect of daily SST at Michaelmas Cay on (a) age-adjusted $M_{\text {INDEX }}$ during 'Foraging Regime 2' $(\bullet, 15$ September to 3 October) of 2004 and (o, 20 May to 22 June) of 2005 and on (b) age-adjusted $F_{\mathrm{FREQ}}$ in Foraging Regime 2 of $2004(\bullet)$ and 2005 (०) 


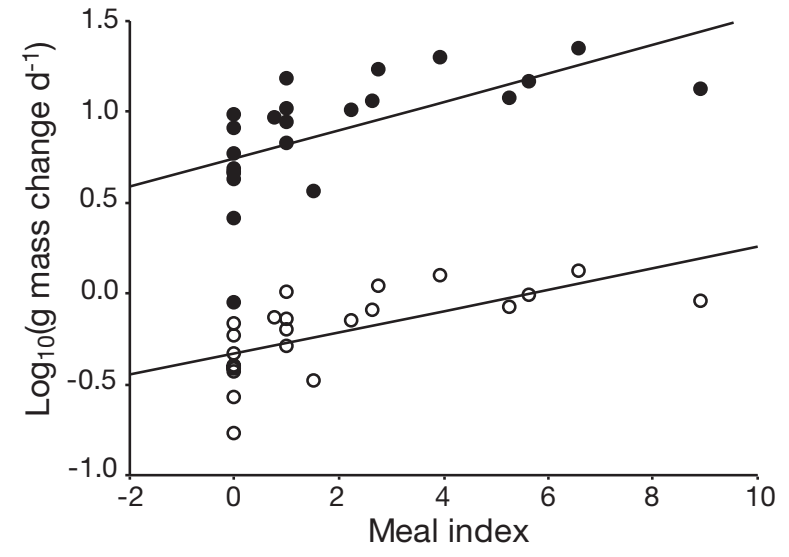

Fig. 4. Sterna fuscata. Relative change in chick mass in relation to $M_{\text {INDEX }}\left(\bullet, \log _{10}\right.$ mass change $g=0.0782 M_{\text {INDEX }}+$ 0.743 ) and chick mass change per day of age relative to $M_{\text {INDEX }}\left(\mathrm{O}, \log _{10}\right.$ mass change grams per day of age $=0.0591$ $\mathrm{M}_{\text {INDEX }}-0.330$ )

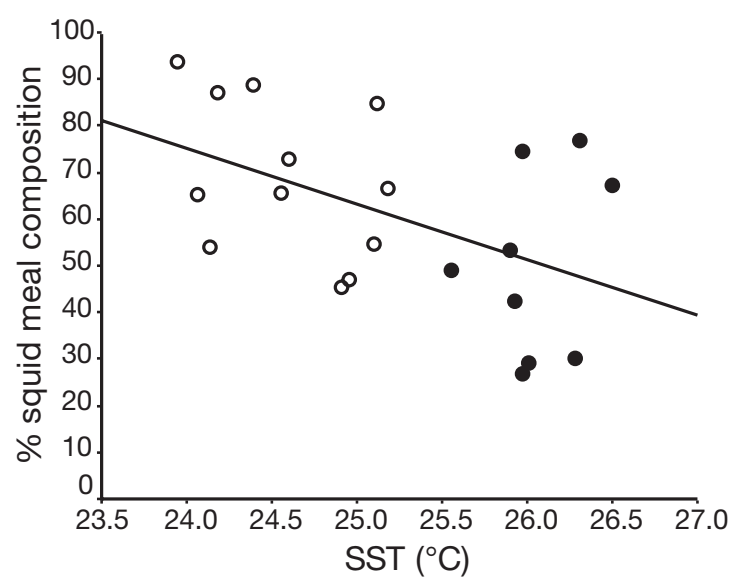

Fig. 5. Sterna fuscata. Significant relationship between daily SST at Michaelmas Cay and percent squid meal composition during the entire 2005 study period, where (•) and (O) represent the Foraging Regimes 1 and 2, respectively

at daily meal index values $<9.50$ and 5.58, respectively, chick mass change and chick mass change per day of age were no longer positive.

\section{Meal composition}

There was a significant negative relationship between $\mathrm{SST}_{\mathrm{MC}}$ and percent squid brought to the colony during the entire study period of $2005\left(F_{1,19}=6.101\right.$, adjusted $r^{2}=0.203, p=0.023$; Fig. 5), implying a significant positive relationship between percent fish and $\mathrm{SST}_{\mathrm{MC}}$ over the same period. However, there were no detectable relationships between either the percent squid or fish in meals fed to chicks and $\mathrm{SST}_{\mathrm{MC} / \mathrm{Broad}}$ during all of 2004 or during any of the sub-periods previously identified in each year (Table 2).

\section{Foraging success in relation to fisheries}

The mean fisheries catch for all days during the study was significantly more variable in $2004\left(F_{1,33}=\right.$ $5.565, \mathrm{p}=0.024)$. Mean $( \pm \mathrm{SE})$ daily catch rate was also significantly higher during the period when SST effects were not apparent in 2004 (Regime 1: $2453.20 \pm$ $721.48 \mathrm{~kg} \mathrm{~d}^{-1}$, Regime 2: $583.36 \pm 152.56 \mathrm{~kg} \mathrm{~d}^{-1}$; MannWhitney $Z=-2.322, \mathrm{p}=0.019, \mathrm{n}=16$ ), but not during 2005 (Regime 1: $387.29 \pm 126.92 \mathrm{~kg} \mathrm{~d}^{-1}$, Regime 2: $918.75 \pm 282.96 \mathrm{~kg} \mathrm{~d}^{-1}$; Mann-Whitney $Z=-0.767, \mathrm{p}=$ $0.482, \mathrm{n}=19$ ).

During foraging Regime 1, when SST did not influence foraging success, mean daily ETBF catch rates were a weak, but significant, positive predictor of the total and age-adjusted amount of food that came into the colony. For example, during Foraging Regime 1 for both years combined, meal daily catch rate was a significant positive predictor of both meal index $\left(F_{1,10}=\right.$ 9.136, adjusted $\left.\mathrm{r}^{2}=0.425, \mathrm{p}=0.013\right)$ and age-adjusted meal index $\left(F_{1,10}=9.755\right.$, adjusted $\mathrm{r}^{2}=0.443, \mathrm{p}=0.011$, Fig. 6), but not feeding frequency $\left(F_{1,10}=1.086\right.$, adjusted $\mathrm{r}^{2}=0.008, \mathrm{p}=0.322$ ) or age-adjusted feeding frequency $\left(F_{1,10}=1.707\right.$, adjusted $\left.\mathrm{r}^{2}=0.060, \mathrm{p}=0.221\right)$. In contrast, when SST effects were apparent in both years (Foraging Regime 2), there were no significant relationships between ETBF catch rates and any of the foraging variables (meal index: $F_{1,19}=0.081$, adjusted $\mathrm{r}^{2}=-0.048, \mathrm{p}=0.779 ;$ age-adjusted meal index: $F_{1,19}=$ 0.111 , adjusted $r^{2}=-0.047, p=0.743$; feeding fre-

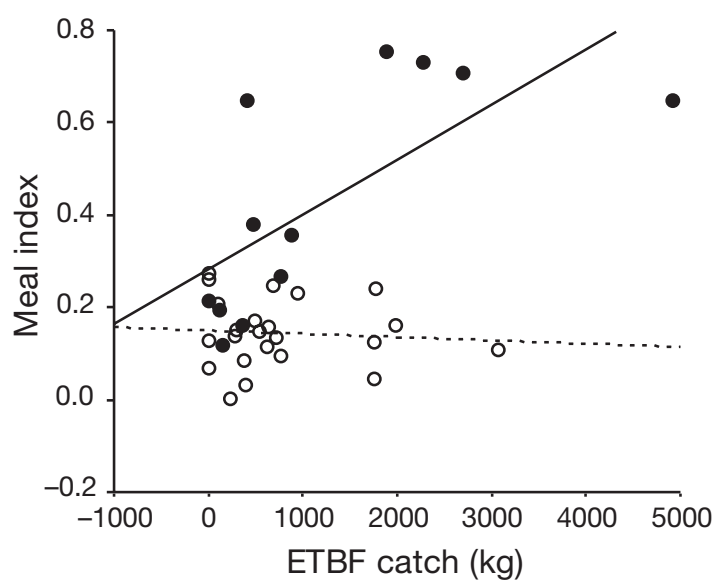

Fig. 6. Sterna fuscata. Significant relationship between Eastern Tuna and Billfish Fisheries (ETBF) daily mean catch (kg) and age-adjusted meal index during Foraging Regime $1(\bullet)$ of both years combined and the non-relationship between the 2 parameters in Foraging Regime 2 ( 0 ) of both years combined 
Table 2. Sterna fuscata. Regression analysis results describing relationships between SST at Michaelmas Cay (SST $\mathrm{MC}_{\mathrm{MC}}$ and sooty tern chick meal composition (percent squid and fish) at Michaelmas Cay during contrasting regimes and during both regimes

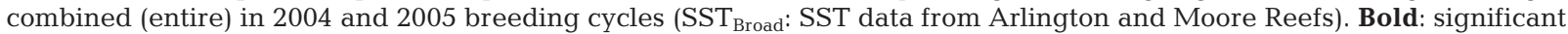

\begin{tabular}{|c|c|c|c|c|c|c|c|c|}
\hline \multirow[t]{2}{*}{ Dependent variable } & \multicolumn{4}{|c|}{$\mathrm{SST}_{\text {Broad }}(2004)$} & \multicolumn{4}{|c|}{$\mathrm{SST}_{\mathrm{MC}}(2005)$} \\
\hline & Regime & $F$ & Adjusted $r^{2}$ & $\mathrm{p}$ & Regime & $F$ & Adjusted $r^{2}$ & $\mathrm{p}$ \\
\hline \multirow[t]{3}{*}{ Percent squid observed } & $1 \mathrm{st}$ & $F_{1,3}=0.000$ & -0.333 & 0.998 & $1 \mathrm{st}$ & $F_{1,7}=0.545$ & -0.060 & 0.484 \\
\hline & 2 nd & $F_{1,9}=0.218$ & -0.085 & 0.652 & 2nd & $F_{1,10}=2.037$ & 0.086 & 0.184 \\
\hline & Entire & $F_{1,14}=0.644$ & -0.024 & 0.436 & Entire & $F_{1,19}=6.101$ & 0.203 & 0.023 \\
\hline \multirow[t]{3}{*}{ Percent fish observed } & $1 \mathrm{st}$ & $F_{1,3}=0.005$ & -0.331 & 0.951 & $1 \mathrm{st}$ & $F_{1,7}=0.031$ & -0.138 & 0.866 \\
\hline & 2nd & $F_{1,9}=0.256$ & -0.080 & 0.625 & 2nd & $F_{1,10}=1.968$ & -0.081 & 0.191 \\
\hline & Entire & $F_{1,14}=0.002$ & -0.071 & 0.963 & Entire & $F_{1,19}=10.247$ & 0.316 & 0.005 \\
\hline
\end{tabular}

quency: $F_{1,19}=0.261$, adjusted $\mathrm{r}^{2}=-0.038, \mathrm{p}=0.615$; age-adjusted feeding frequency: $F_{1,19}=0.096$, adjusted $\mathrm{r}^{2}=-0.047, \mathrm{p}=0.761$; Fig. 6). There were also no significant effects of $\mathrm{SST}_{\mathrm{MC} / \text { Broad }}$ on mean daily ETBF catch rates in either year (2004: $F_{1,14}=1.499$, adjusted $\mathrm{r}^{2}=0.032, \mathrm{p}=0.241 ; 2005: F_{1,17}=0.020$, adjusted $\mathrm{r}^{2}=$ $-0.058, \mathrm{p}=0.888)$ or in both years combined $\left(F_{1,33}=\right.$ 0.086 , adjusted $r^{2}=-0.028, p=0.771$ ).

\section{DISCUSSION}

During the second two-thirds of each sooty tern Sterna fuscata breeding cycle in 2004 and 2005, significant negative relationships were observed between increasing SST and both the amount of food delivered to chicks and the rate of delivery. These results were consistent for feeding frequency across years, but were uniformly significant for meal index only when meal sizes from 2004 were adjusted for chick age/energy requirements.

During 2004, total meal size suggests that food was generally less abundant. At this time our foraging data suggest that sooty tern adults returned to the colony with relatively constant absolute food loads (i.e. possibly the minimum obtained during a successful foraging dive), but that both the time taken to obtain this load and its size relative to chick needs decreased as SST increased. By comparison, during 2005, both absolute and relative food loads decreased with increasing SST as did the time taken to obtain each meal.

Both age-adjusted feeding frequency and ageadjusted meal size responded to changes in SST in a similar manner among years. However, during 2004, both variables were consistently lower for the same SST. In 2004, SST generally increased as chick age increased. Conversely, in 2005, SST generally decreased as chick age increased. Therefore, in 2004, meal index and feeding frequency may have been more sensitive to changing SST, not only because food was generally less abundant that year, but also because both SSTs and chick age/requirements were increasing simultaneously. Consistency in the rate of change between years suggests that despite inferred differences in food availability and chick development stage, short-term variation in SST impacts sooty tern provisioning similarly across breeding seasons and across temperature ranges of $\sim 23$ to $26^{\circ} \mathrm{C}$.

While correlations do not necessarily imply direct causation, our findings combined with existing data on SST effects in other seabird species, strongly suggest that changes in prey availability associated with increasing SST reduced the ability of sooty tern adults to provision young. These effects were observed for up to $3 \mathrm{wk}$ during the mid- to late chick-rearing period in both 2004 and 2005. Our results also suggest that feeding frequency is more sensitive to changes in SST than meal size. These findings are consistent with the results obtained for wedge-tailed shearwaters Puffinus pacificus breeding in the southern GBR, where feeding frequency was also found to be more significantly affected by within-season fluctuations in SST (Peck et al. 2004).

In general, seabirds are not always able to compensate for changes in the distribution or abundance of forage-fish by increasing food loads or foraging rates (Gjerdrum et al. 2003). Our results suggest that sooty terns, like wedge-tailed shearwaters (Peck et al. 2004), are not always able to increase foraging rates enough when prey are scarce during periods of enhanced SSTs.

Data from this study were used to determine that each $1^{\circ} \mathrm{C}$ SST increase results in approximately $8 \%$ decrease in the meal index brought to chicks. Thus, there is clear potential for detrimental impacts of shortterm temperature variation of just a few degrees. Small increases in temperature for sustained periods of several days or weeks may lead to decreased growth and survival. For example, 2 wk of low food availability caused virtually all tropical roseate tern Sterna dougallii chicks to die of starvation in 1997, while, in the subsequent season, chicks recovered after only $6 \mathrm{~d}$ of low food availability (Ramos 2000). 
No relationship between SST and foraging success was apparent during the first one-third of the study period in either year (6 to 13 September 2004/6 May to 19 May 2005) when prey availability was $\sim 10$ to 15 times greater. During both breeding seasons this period coincided with earlier stages of chick-rearing. Adult sooty terns have been shown to forage in different areas when brooding (290 $\mathrm{km}$ foraging radius) and when feeding older chicks (522 km foraging radius) (Flint 1991). Sooty terns may also feed young chicks a greater number of small meals compared to older chicks (Dinsmore 1972, Feare 1976); however, our observations of provisioning of young chicks over intervals of $\sim 1$ to $4 \mathrm{~h}$ suggest this phenomenon did not impact our results.

Alternatively, the rapid change in prey availability that occurred over a very short 2 to $3 \mathrm{~d}$ period in both years highlights that other potential short-term, within-season mechanisms must also significantly influence prey accessibility and foraging potential. One possibility is the distribution of subsurface predators. Intra-annual variation in sooty tern foraging success has already been shown to be highly influenced by the distribution of underwater predators, especially tuna (Le Corre \& Jaquemet 2005). A significant positive relationship between the provisioning rates and ETBF sub-surface predator catch rates is evidence of the potential influence of this phenomenon on our data. In both seasons, the presence of sub-surface predators either mitigated the impact of SST variability on sooty tern foraging success or predator numbers also declined in response to a rapid decrease in foragefish availability. Unfortunately, it is not possible to distinguish between these 2 alternatives with the current dataset. The 2005 data also suggest that at some times of year a relationship may exist between the availability of specific prey types and SST. Regardless of the mechanisms involved, our results imply that it is not just large seasonal-scale phenomena that impact reproductive success, but also short-term within-season changes in both SST and other factors. How these other potential factors interact with oceanography and whether they are also influenced by climate change is currently unknown and requires further clarification.

Results from this study show that prey availability can track SST for periods of up to 1 mo and that feeding frequency is a more sensitive indicator of how SST impacts sooty tern foraging success. These findings when combined with those of Peck et al. (2004) suggest that SST variation may impact the foraging success of multiple tropical seabird species at a reef-wide scale. Such results further support a potentially significant negative effect of forecasted climatic changes on seabird reproduction on the GBR. As global climate change continues to increase average SSTs on the GBR at a rate of 1 to $2{ }^{\circ} \mathrm{C}$ per century (Hoegh-Guldberg 1999), our findings have significant conservation and management implications.

These results further support earlier findings that, while longer-term impacts of climate fluctuations such as ENSO are important to tropical systems (Schreiber \& Schreiber 1984), even during non-ENSO years the potential effect of short-term climate variation on seabird reproductive output cannot be ignored. Indeed, short-term declines in food availability for periods of days and weeks have resulted in reduced reproductive success (Ramos 2000, Peck et al. 2004) and seasonal declines in nestling growth rates (Gjerdrum et al. 2003), although the severity of these impacts appears to be related to the number of days of reduced provisioning (Ramos 2000).

The relative importance of within-season, climaterelated variation in foraging success in the broader context of interannual, decadal-scale, climate-related variation is unclear and complex. For example, the number of wedge-tailed shearwater burrows excavated each season is most related to the cumulative impact of oceanographic conditions from previous breeding seasons (Dunlop et al. 2002), while the percentage of burrows in which eggs were laid is correlated with prevailing feeding conditions during the pre-laying season, and the final breeding outcome is related to short-term environmental conditions during the chick-rearing period (Peck et al. 2004). While interseasonal ENSO-associated variation in environmental parameters such as SST may influence the timing and result of a breeding attempt, intra-seasonal variation in SST may be as important for the actual breeding outcome.

Information about the mechanistic links between climate, oceanography and seabird reproduction is vital if the predicted changes in climate are to be successfully managed in the future. Our results highlight pelagic foraging seabirds with single egg clutches, such as sooty terns and wedge-tailed shearwaters, as useful for identifying broader scale trophic changes that may be occurring and as indicators of how climate change may be impacting other less abundant species within the GBR ecosystem.

Acknowledgements. We sincerely thank M. Short (QPWS, Cairns), the crew and managers of 'Ocean Spirit' cruises and the QPWS 'Reef Heron' crew. Volunteers D. Devney, A. Adkins and P. Yuda contributed to collection of chick provisioning data. Thanks also to P. Marshall (GRBMPA) for logistical assistance, R. Berkelmans and J. Lough (AIMS) for providing SST data, B. Baker (Australian Antarctic Division) and P. Sahlqvist (AFMA) for providing fisheries data, and D. R. Peck (JCU) for comments on the manuscript. Essential funding was provided by Queensland Parks and Wildlife Service, Cairns, JCU Graduate Research Support Scheme Grant, 
Stuart Leslie Bird Research Award and GBRMPA Science for Management Award. Work was authorised under QPWS Permit WITK02630504, Australian Bird and Band Banding Scheme Authority Numbers 1386 and 2665 and JCU Ethics Approval A944_04.

\section{LITERATURE CITED}

Ainley DG, Carter HR, Anderson DW, Briggs KT and 8 others (1988) ENSO effects on Pacific Ocean marine bird populations. In: Ouellet $\mathrm{H}$ (ed) Acta 19th Congressus Internationalis Ornithologici. University of Ottawa Press, p 1747-1758

Anderson DW, Gress F, Mais KF (1982) Brown pelicans: influence of food supply on reproduction. Oikos 39:23-31

Ashmole NP (1963) The biology of the wideawake or sooty tern on Ascension Island. Ibis 103:297-364

Ashmole NP, Ashmole MJ (1967) Comparative feeding ecology of sea birds of a tropical oceanic island. Peabody Mus Nat Hist Yale Univ Bull 24:1-131

Au DWK, Pitman RL (1986) Seabird interactions with dolphins and tuna in the eastern tropical Pacific. Condor 88: 304-317

Batianoff GN, Cornelius NJ (2005) Birds of Raine Island: population trends, breeding behaviour and nesting habitats. Proc R Soc Queensl 112:1-29

Blaber SJM, Milton DA, Farmer MJ, Smith GC (1998) Seabird breeding populations on the far northern Great Barrier Reef, Australia: trends and influences. Emu 98: 44-57

Brooke MdL (2004) The food consumption of the world's seabirds. Proc R Soc Lond B Biol Sci 271:246-248

Burger AE, Piatt JF (1990) Flexible time budgets in breeding common murres: buffers against variable prey abundance. Stud Avian Biol 14:71-83

Davis ND, Myers KW, Ishida Y (1998) Caloric value of high seas salmon prey organisms and simulated salmon ocean growth and prey consumption. North Pac Anadromous Fish Comm Bull 1:146-162

Dinsmore JJ (1972) Sooty tern behaviour. Bull Fla State Mus Biol Sci 16:129-179

Duffy DC (1990) Seabirds and the 1982-84 El Niño southern oscillation. In: Glynn PW (ed) Global ecological consequences of the 1982-83 El Niño southern oscillation. Elsevier, Amsterdam, p 395-415

Dunlop JN, Long P, Stejskal I, Surman C (2002) Inter-annual variations in breeding participation at four Western Australian colonies of the wedge-tailed shearwater Puffinus pacificus. Mar Ornithol 30:13-18

Feare CJ (1976) The breeding of the sooty tern Sterna fuscata in the Seychelles and the effects of experimental removal of its eggs. J Zool 179:317-360

Feare CJ (2002) Influence of date and body mass at fledging on long-term survival of sooty terns Sterna fuscata. Mar Ornithol 30:46-47

Flint EN (1991) Time and energy limits to the foraging radius of sooty terns Sterna fuscata. Ibis 133:43-46

Forbes LS, Sealy SG (1990) Foraging roles of male and female western grebes during brood rearing. Condor 92:421-426

Frederiksen M, Harris MP, Daunt F, Rothery P, Wanless S (2004) Scale-dependent climate signals drive breeding phenology of three seabird species. Global Change Biol $10: 1214-1221$

Gaston AJ (2001) Taxonomy and conservation: thoughts on the latest BirdLife International listings for seabirds. Mar Ornithol 29:1-6
GBRMPA (Great Barrier Reef Marine Park Authority) (1986) Michaelmas management plan. GBRMPA, Townsville

GBRMPA (Great Barrier Reef Marine Park Authority) (1998) State of the Great Barrier Reef World Heritage Area report-Birds. GBRMPA, Townsville

GBRMPA (Great Barrier Reef Marine Park Authority) (2002) Cairns area plan of management. GBRMPA, Townsville

Gjerdrum C, Vallée AMJ, Cassady St. Clair C, Bertram DF, Ryder JL, Blackburn GS (2003) Tufted puffin reproduction reveals ocean climate variability. Proc Natl Acad Sci USA 100:9377-9382

Harrison CS, Hida TS, Seki MP (1983) Hawaiian seabird feeding ecology. Wildl Monogr 85:1-71

Higgins PJ, Davies SJJF (1996) Handbook of Australian, New Zealand and Antarctic birds, Vol 3. Snipe to pigeons. Oxford University Press, Melbourne

Hoegh-Guldberg O (1999) Climate change, coral bleaching and the future of the world's coral reefs. Mar Freshw Res 50:839-866

Hughes L (2003) Climate change and Australia: trends, projections and impacts. Austral Ecol 28:423-443

Hunt GL, Priddle J, Whitehouse MJ, Veit RR, Heywood RB (1992) Changes in seabird species abundance near South Georgia during a period of rapid change in sea surface temperature. Antarct Sci 4:15-22

Inchausti P, Guinet C, Koudil M, Durbec JP, Barbraud C, Weimerskirch H, Cherel Y, Jouventin P (2003) Interannual variability in the breeding performance of seabirds in relation to oceanographic anomalies that affect the Crozet and the Kerguelen sectors of the Southern Ocean. J Avian Biol 34:170-176

IPCC (Intergovernmental Panel on Climate Change) (2001) Climate change 2001: impacts, adaptation and vulnerability. IPCC, Geneva

Jaquemet S, Le Corre M, Weimerskirch H (2004) Seabird community structure in a coastal tropical environment: importance of associations with sub-surface predators and of Fish Aggregating Devices (FADs). Mar Ecol Prog Ser 268:281-292

King BR (1985) Seabird islands: Michaelmas Cay, Great Barrier Reef, Queensland. Corella 9:94-96

King BR, Hicks JT, Cornelius J (1992) Population changes, breeding cycles and breeding success over six years in a seabird colony at Michaelmas Cay, Queensland. Emu 92: $1-10$

Kitaysky AS, Goluvova EG (2000) Climate change causes contrasting trends in reproductive performance of planktivorous and piscivorous alcids. J Anim Ecol 69:248-262

Le Corre M (2001) Breeding seasons of seabirds at Europa Island (southern Mozambique Channel) in relation to seasonal changes in the marine environment. J Zool 254: 239-249

Le Corre M, Jaquemet S (2005) Assessment of the seabird community of the Mozambique Channel and its potential use as an indicator of tuna abundance. Estuar Coast Shelf Sci 63:421-428

Lough JM (2000) 1997-98: unprecedented thermal stress to coral reefs? Geophys Res Lett 27:3901-3904

Lunney D, Curtin AL, Ayers D, Cogger HG, Dickman CR, Maitz W, Law B, Fisher D (2000) The threatened and nonthreatened native vertebrate fauna of New South Wales: status and ecological attributes. Environment and Heritage Monograph Series No. 4, National Parks \& Wildlife Service (NPWS), Sydney

Lyver POB, Moller H, Thompson C (1999) Changes in sooty shearwater Puffinus griseus chick production and harvest precede ENSO events. Mar Ecol Prog Ser 188:237-248 
McIlwain JL (2003) Fine-scale temporal and spatial patterns of larval supply to a fringing reef in Western Australia. Mar Ecol Prog Ser 252:207-222

Peck DR, Smithers BV, Krockenberger AK, Congdon BC (2004) Sea surface temperature constrains wedge-tailed shearwater foraging success within breeding seasons. Mar Ecol Prog Ser 281:259-266

Phillips RA, Hamer KC (2000) Periodic weighing and the assessment of meal mass and feeding frequency in birds. J Avian Biol 31:75-80

Ramos JA (2000) Characteristics of foraging habitats and chick food provisioning by tropical roseate terns. Condor 102:795-803

Ramos JA, Maul AM, Ayrton V, Bullock I and 5 others (2002) Influence of local and large-scale weather events and timing of breeding on tropical roseate tern reproductive parameters. Mar Ecol Prog Ser 243:271-279

Ricklefs RE, White SC (1981) Growth and energetics of chicks of the sooty tern (Sterna fuscata) and common tern ( $S$. hirundo). Auk 98:361-378

Ricklefs RE, Day CH, Huntington CE, Williams JB (1985) Variability in feeding rate and meal size of Leach's storm-petrel at Kent Island, New Brunswick. J Anim Ecol 54:883-898

Ridley MW, Percy R (1958) The exploitation of sea birds in Seychelles. Her Majesty's Stationery Office, London

Schreiber RW, Schreiber EA (1984) Central Pacific seabirds and the El Niño southern oscillation: 1982 to 1983 perspectives. Science 225:713-715

Schreiber EA, Feare CJ, Harrington BA, Murray BGJ, Robertson WBJ, Woolfenden GE (2002) Sooty tern (Sterna fuscata). In: Poole A, Gill F (eds) Birds of North America, Vol 665. The Birds of North America, Philadelphia, PA

Editorial responsibility: Otto Kinne (Editor-in-Chief), Oldendorf/Luhe, Germany
Shealer DA (1998) Differences in diet and chick provisioning between adult roseate and sandwich terns in Puerto Rico. Condor 100:131-140

Smithers BV, Peck DR, Krockenberger AK, Congdon BC (2003) Elevated sea-surface temperature, reduced provisioning and reproductive failure of wedge-tailed shearwaters (Puffinus pacificus) in the southern Great Barrier Reef, Australia. Mar Freshw Res 54:973-977

Spear LB, Ballance LT, Ainley DG (2001) Response of seabirds to thermal boundaries in the tropical Pacific: the thermocline versus the Equatorial Front. Mar Ecol Prog Ser 219: 275-289

SPSS (2001) SPSS for Windows. SPSS, Chicago, IL

Stenseth NC, Mysterud A, Ottersen G, Hurrell JW, Chan KS, Lima M (2002) Ecological effects of climate fluctuations. Science 297:1292-1296

Surman C, Wooller RD (2003) Comparative foraging ecology of five sympatric terns at a sub-tropical island in the eastern Indian Ocean. J Zool 259:219-230

Surman C, Moran M, Burbidge A, Wooller R, Gaughan D (2002) Identification and conservation of food fish for Abrolhos seabirds. National Heritage Trust, Perth, Western Australia

Suryan RM, Irons DB, Kaufman M, Benson J, Jodice PGR, Roby DD, Brown ED (2002) Short-term fluctuations in forage fish availability and the effect on prey selection and brood-rearing in the black-legged kittiwake. Mar Ecol Prog Ser 236:273-287

Veit RR, McGowan JA, Ainley DG, Wahls TR, Pyle P (1997) Apex marine predator declines ninety percent in association with changing ocean climate. Global Change Biol 3: $23-28$

Submitted: November 25, 2005; Accepted: July 19, 2006 Proofs received from author(s): January 30, 2007 